\title{
Organization of the European Bacillus subtilis genome sequencing project
}

\author{
Frank Kunst, ${ }^{1 *}$ Ati Vassarotti ${ }^{2} \dagger$ and Antoine Danchin ${ }^{3} \ddagger$
}

Author for correspondence: Frank Kunst. Tel: +331456888 69. Fax: +3314568 8938. e-mail: fkunst@pasteur.fr

\begin{abstract}
1,3 Unité de Biochimie Microbienne ${ }^{1}$ and Unité de Régulation de l'Expression Génétique, ${ }^{3}$ Institut Pasteur, 25-28 rue du Dr Roux, 75724 Paris Cedex 15, France

2European Commission, DG XII, SDME 2/78 Rue de la Loi 200, B-1049 Brussels, Belgium
\end{abstract}

Keywords: Bacillus subtilis, genome project, genome sequencing

\section{Introduction}

Several genome sequencing projects of model organisms have recently been initiated, including several prokaryotes such as Eschericbia coli (Sofia et al., 1994), Bacillus subtilis, Mycobacterium leprae (Bergh \& Cole, 1994) and Mycoplasma genitalium (Peterson et al., 1993). The genome sequencing of three model organisms is presently supported by the European Commission (EC) under the Biotechnology programme: Saccharomyces cerevisiae (Oliver et al., 1992; Vassarotti \& Goffeau, 1992; Dujon et al., 1994), Arabidopsis thaliana (Magnien et al., 1992) and B. subtilis (Glaser et al., 1993; Sorokin et al., 1993; Azevedo et al., 1993b; Daniel \& Errington, 1993; Scotti et al., 1993). The genome sequencing of a fourth model organism, Caenorbabditis elegans, was initiated as a British-American collaborative project (Wilson et al., 1994).

The advantages of such a systematic approach in the case of $B$. subtilis have recently been described (Glaser $e t$ al., 1993; Sorokin et al., 1993). It allows us to get a complete blueprint of the genetic content of an organism and it contributes key information to the understanding of molecular evolution. Gram-negative and Gram-positive bacteria diverged more than 2 billion years ago (Woese, 1987), underscoring the importance of sequencing in parallel the genomes of both E. coli and B. subtilis.

\section{The participants}

In September 1989 a consortium of five European laboratories started a joint project aimed at developing the physical map, constructing appropriate DNA libraries and launching on a pilot scale the systematic sequencing of the B. subtilis genome (Kunst \& Devine, 1991). These

\footnotetext{
* Administrative coordinator of the project.

† Scientific officer at the European Commission.

$\ddagger$ Coordinator of data handling.
}

laboratories, listed as numbers $1-5$ in Table 1 , were supported by the European Commission (EC) for an 18 month period in the framework of the SCIENCE programme. The coordinator during this stage of the project was R. Dedonder (Institut Pasteur, Paris, France), who is presently participating in the project as a scientific adviser.

In August 1993 four additional laboratories (numbers 6-9, Table 1) joined the project in the frame of the BIOTECHNOLOGY programme of the EC. The laboratory of D. Karamata (laboratory number 10, Table 1) participates in this project as a non-European Union member using funds obtained from the Swiss government. A new contract allowing participation of seven additional laboratories has recently been finalized with the EC (laboratory numbers 11-17, Table 1). A FinnishAmerican Company, Genencor (San Francisco, USA) participates in the European project using its own funds.

Different DNA regions were assigned to these laboratories (see below); each laboratory is in charge of both cloning and sequencing of its assigned DNA region and chooses its own strategy to achieve this goal.

Thus the original project has grown from a core of five laboratories into a major European sequencing initiative carried out in close cooperation with the Japanese project involving the participation of seven laboratories (Ogasawara et al., 1995). Since detailed genetic and physical maps are available for the $B$. subtilis chromosome (Amjad et al., 1990; Itaya \& Tanaka, 1991; Anagnostopoulos et al., 1993), it was possible to assign precisely DNA regions flanked by well identified genetic markers or - whenever possible - by already sequenced genes to the different participating laboratories as indicated in Fig. 1. This international subdivision of the genome has been achieved by direct negotiation between the scientists who had obtained funds to carry out sequencing projects, taking into account individual scientific interests in specific DNA 
Table 1. Contact addresses of the European laboratories participating in the $B$. subtilis genome sequencing project

\begin{tabular}{|c|c|c|}
\hline $\begin{array}{l}\text { Laboratory } \\
\text { number }\end{array}$ & $\begin{array}{c}\text { Principal } \\
\text { investigator(s) }\end{array}$ & Contact address \\
\hline 1 & $\begin{array}{l}\text { A. Danchin \& } \\
\text { G. Rapoport }\end{array}$ & $\begin{array}{l}\text { Institut Pasteur, 25-28, rue du Dr Roux, } 75724 \text { Paris Cedex 15, } \\
\text { France } \\
\text { Fax: }+33145688948 / 38 \\
\text { e-mail: adanchin@pasteur.fr }\end{array}$ \\
\hline 2 & J. Errington & $\begin{array}{l}\text { Sir William Dunn School of Pathology, University of Oxford, } \\
\text { South Parks Road, Oxford OX1 3RE, UK } \\
\text { Fax: +44 } 1865275556 \\
\text { e-mail: erring@molbiol.ox.ac.uk }\end{array}$ \\
\hline 3 & $\begin{array}{l}\text { A. Galizzi \& } \\
\text { A. Albertini }\end{array}$ & $\begin{array}{l}\text { University of Pavia, Via Abbiategrasso, 207, } 27100 \text { Pavia, Italy } \\
\text { Fax: + } 39382528496 \\
\text { e-mail: ALBERTINI@ipvgen.unipv.it }\end{array}$ \\
\hline 4 & S. D. Ehrlich & $\begin{array}{l}\text { Laboratoire de Génétique Microbienne, Institut de Biotech- } \\
\text { nologie, INRA, Domaine de Vilvert, } 78352 \text { Jouy-en-Josas } \\
\text { Cedex, France } \\
\text { Fax: + } 33134652521 \\
\text { e-mail: ehrlich@ biotec.jouy.inra.fr }\end{array}$ \\
\hline 5 & K. Devine & $\begin{array}{l}\text { Department of Genetics, Trinity College, Lincoln Place Gate, } \\
\text { Dublin 2, Republic of Ireland } \\
\text { Fax: + } 35316798558 \\
\text { e-mail: kdevine@vax1.tcd.ie }\end{array}$ \\
\hline 6 & S. Bron & $\begin{array}{l}\text { Department of Genetics, University of Groningen, Kerklaan 30, } \\
9751 \text { NN Haren, The Netherlands } \\
\text { Fax: + } 3150632348 \\
\text { e-mail: S.Bron@biol. rug.nl }\end{array}$ \\
\hline 7 & $\begin{array}{l}\text { C. Harwood \& } \\
\text { P. Emmerson }\end{array}$ & $\begin{array}{l}\text { Department of Microbiology, The Medical School, University of } \\
\text { Newcastle, Framlington Place, Newcastle upon Tyne NE2 4HH, } \\
\text { UK } \\
\text { Fax: +44 } 1912227736 \\
\text { e-mail: colin.harwood@newcastle.ac.uk }\end{array}$ \\
\hline 8 & R. Mellado & $\begin{array}{l}\text { Centro Nacional de Biotecnologia (CSIC), Campus Universidad } \\
\text { Autonoma, Cantoblanco, } 28049 \text { Madrid, Spain } \\
\text { Fax: + } 3415854506 \\
\text { e-mail: rpmellado@Samba.cnb.uam.es }\end{array}$ \\
\hline 9 & G. Grandi & $\begin{array}{l}\text { Eniricherche S.P.A., Via Maritano, 26, San Donato Milanese, } \\
20097 \text { Milan, Italy } \\
\text { Fax: + } 3925204422 \\
\text { e-mail: ergrandi@galactica.it }\end{array}$ \\
\hline 10 & $\begin{array}{l}\text { D. Karamata \& } \\
\text { C. Mauel }\end{array}$ & $\begin{array}{l}\text { Institut de Génétique et de Biologie Microbiennes, } 19 \text { rue César } \\
\text { Roux, } 1005 \text { Lausanne, Switzerland } \\
\text { Fax: +41213206 078 } \\
\text { e-mail: CMauel@IGBM.UNIL.CH }\end{array}$ \\
\hline 11 & $\begin{array}{l}\text { J. Haiech \& } \\
\text { F. Denizot }\end{array}$ & $\begin{array}{l}\text { CNRS, BP 71, Laboratoire de Chimie Bactérienne, } 31 \text { Chemin } \\
\text { Joseph Aguier, } 13402 \text { Marseille Cedex 09, France } \\
\text { Fax: + } 3391718914 \\
\text { e-mail: DENIZOT@LCB.CNRS-MRS.FR }\end{array}$ \\
\hline 12 & B. Oudega & $\begin{array}{l}\text { Vrije Universiteit Amsterdam, Faculty of Biology, De Boelelaan } \\
\text { 1087, Amsterdam } 1081 \text { HV, The Netherlands } \\
\text { Fax: +31 } 204447123 \\
\text { e-mail: OUDEGA@BIO.VU.NL }\end{array}$ \\
\hline
\end{tabular}




\section{Table 1 (cont.)}

\begin{tabular}{|c|c|c|}
\hline $\begin{array}{c}\text { Laboratory } \\
\text { number }\end{array}$ & $\begin{array}{c}\text { Principal } \\
\text { investigator(s) }\end{array}$ & Contact address \\
\hline 13 & I. Connerton & $\begin{array}{l}\text { BBSRC, Institute of Food Research, Reading Laboratory, Early } \\
\text { Gate, Whiteknights Road, Reading RG6 2EF, UK } \\
\text { Fax: + } 441734267917 \\
\text { e-mail: CONNRTON@BBSRC.AC.UK }\end{array}$ \\
\hline 14 & R. Borriss & $\begin{array}{l}\text { Humboldt Universität, Institut für Genetik und Mikrobiologie, } \\
\text { Warschauer Strasse 43,D } 10243 \text { Berlin, Germany } \\
\text { Fax: +49305800 528 } \\
\text { e-mail: h0135nax@biologie.hu-berlin.de }\end{array}$ \\
\hline 15 & B. Joris & $\begin{array}{l}\text { Université de Liège, Centre d'Ingéniérie des Protéines, Institut de } \\
\text { Chimie B6, Sart Tilman, B-4000 Liège, Belgium } \\
\text { Fax: + } 3241663364 \\
\text { e-mail: ALF@NMR.CIP.ULG.AC.BE }\end{array}$ \\
\hline 16 & S. Seror & $\begin{array}{l}\text { Université Paris 11, Bât. 409, } 91405 \text { Orsay Cedex, France } \\
\text { Fax: +33169417808 } \\
\text { e-mail: seror@igmors.u-psud.fr }\end{array}$ \\
\hline 17 & K. Entian & $\begin{array}{l}\text { Institut für Mikrobiologie, J. W. Goethe Universität, Marie Curie } \\
\text { Strasse 9, Frankfurt am Main 60439, Germany } \\
\text { Fax: +49695800 } 9527 \\
\text { e-mail: KOETTER@EM.UNI-FRANKFURT.D400.DE }\end{array}$ \\
\hline 18 & E. Ferrari & $\begin{array}{l}\text { Genencor International Inc., } 180 \text { Kimball Way, South } \\
\text { San Francisco, CA } 94080 \text {, USA } \\
\text { Fax: +1 } 4155838269 \\
\text { e-mail : gcieuf@class.org }\end{array}$ \\
\hline
\end{tabular}

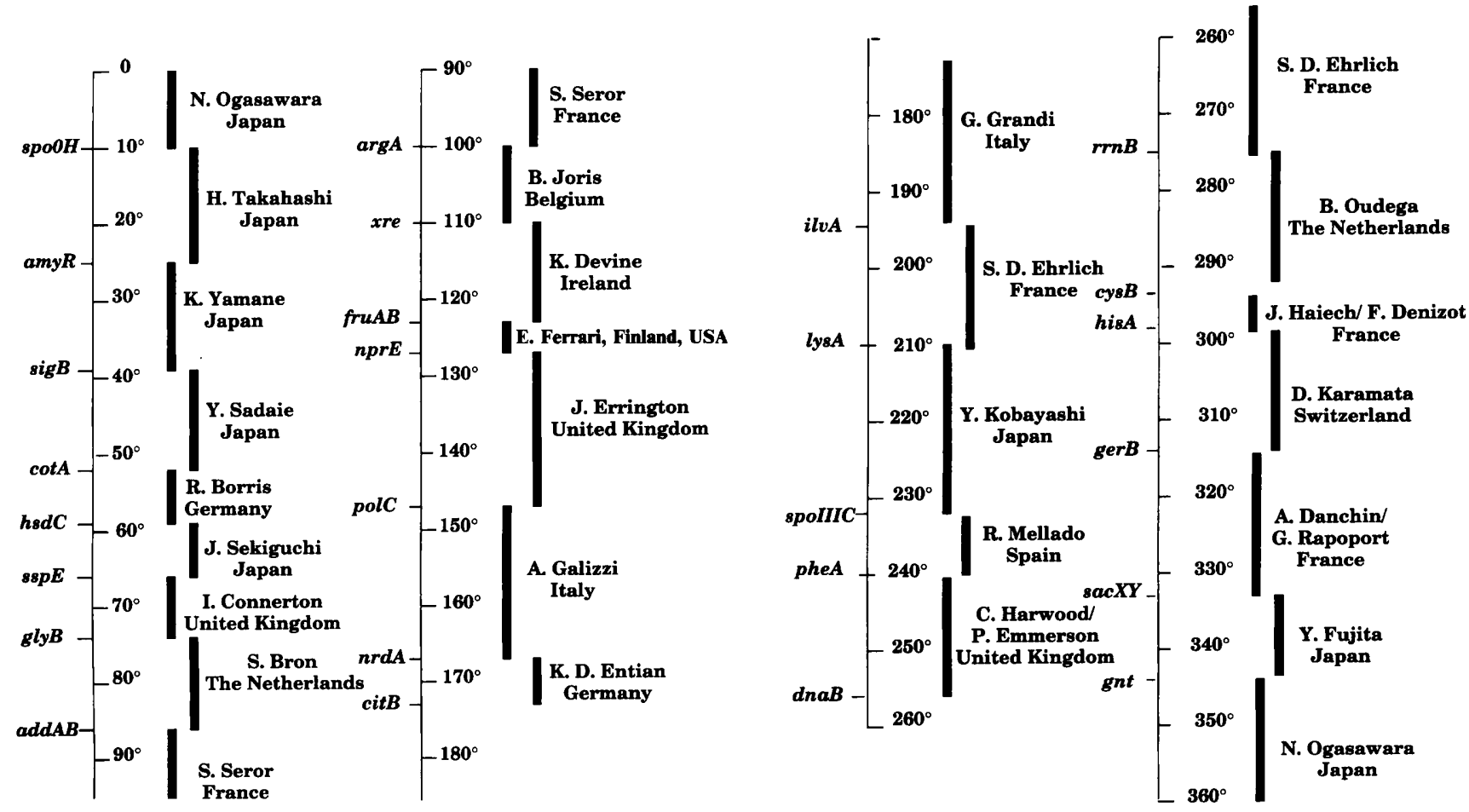

Fig. 1. The DNA regions assigned to the laboratories participating in the international $B$. subtilis genome sequencing project (see Table 1). The names of the principal investigators of these laboratories are indicated and the assigned DNA regions are presented as black bars flanked by the indicated genetic markers. 
Table 2. B. subtilis genes identified and their putative function

The classification is similar to the one proposed by Riley (1993).

I. Metabolism of small molecules

(intermediary metabolism, biosynthesis and degradation of small molecules including sugars, cofactors, fatty acids, antibiotics, electron transport)

\begin{tabular}{|c|c|c|}
\hline Gene name & Similarities & Reference \\
\hline$i p a-1 r$ & Ketoacyl reductase & \\
\hline$i p a-3 r$ & Acyl carrier protein & \\
\hline$i p a-26 d(t b i C)$ & Protein involved in thiamine metabolism & \\
\hline$i p a-58 r$ & Aldehyde dehydrogenase & \\
\hline $\operatorname{roc} A$ & Aldehyde dehydrogenase & Glaser et al. (1993) \\
\hline$i p a-82 d$ & Glucose dehydrogenase & \\
\hline ipa-85d & Aspartate aminotransferase & \\
\hline ipa-86r & Acetoacetyl-CoA reductase & \\
\hline$q \circ \times A, B, C, D$ & Subunits of quinol oxidase & \\
\hline $\operatorname{rib} A, B, G, H$ & Riboflavin synthesis & \\
\hline lys $A$ & DAP decarboxylase & \\
\hline aroC & 3-Dehydroquinase & Sorokin et al. (1993) \\
\hline $\operatorname{ser} A$ & Phosphoglycerate dehydrogenase & \\
\hline $\operatorname{orf} X 14$ & Cytochrome $c$ biogenesis protein & \\
\hline $\arg C-F$ & Arginine biosynthesis & O'Reilly \& Devine (1994) \\
\hline atp & $\mathrm{F}_{0} \mathrm{~F}_{1}$ ATP synthase & Santana et al. (1994) \\
\hline ipa-88d & Phosphotransacetylase & Glaser and others \\
\hline$g l y C$ & Glycine (serine) hydroxymethyltransferase & (unpublished) \\
\hline$u p p$ & Uracil phosphoribosyltransferase & \\
\hline$p k s X$ & Polyketide synthase & Scotti et al. (1993) \\
\hline
\end{tabular}

II. Broad regulatory functions

(including putative regulatory proteins with unidentified targets)

\begin{tabular}{|lll|}
\hline Gene name & \multicolumn{1}{c|}{ Similarities } & \multicolumn{1}{c|}{ Reference } \\
\hline $\begin{array}{l}\text { ipa-24d, ipa-89d } \\
\text { orf } \mathrm{X} 17\end{array}$ & Regulatory proteins of the LysR family & Glaser et al. (1993) \\
orf $\mathrm{X} 18$ & PhoP regulatory protein & Sorokin et al. (1993) \\
\hline
\end{tabular}

III. Macromolecular metabolism

(protein, RNA and DNA metabolism)

\begin{tabular}{|lll|}
\hline Gene name & Similarities & \multicolumn{1}{c|}{ Reference } \\
\hline tyr $Z$ & Tyrosyl-tRNA synthase & Glaser et al. (1993) \\
ipa-57d & Uracil-DNA glycosylase & Glaser et al. (1993) \\
ppiB & Peptidyl prolyl isomerase & Sorokin et al. (1993) \\
\hline
\end{tabular}

regions. The decision has also been taken to concentrate all efforts on the same strain: B. subtilis strain 168.

\section{Cloning and sequencing}

The first results obtained gave us some insight into the requirements for the cloning and analysis of large genome segments. It now appears that the main bottleneck does not occur at the sequencing level but rather at two other levels: the cloning step and data interpretation.

Different strategies were successfully applied to obtain appropriate ordered sublibraries covering portions of the genome: (i) cloning in plasmid, $\lambda$ and YAC vectors; (ii) ordering of $\lambda$ clones using YAC recombinant vectors; (iii) use of integrative plasmids and marker rescue in genome walking experiments; and (iv) in vitro amplification using PCR.

Since $B$. subtilis fragments cloned in $E$. coli are often unstable, attempts to construct complete libraries of overlapping $\lambda$ or cosmid clones failed. However, B. subtilis DNA fragments which were not present in a constructed $\lambda$ library could be cloned by chromosome walking (Kunst \& Devine, 1991; Glaser et al., 1993). This alternative strategy is based on either plasmid rescue or marker 
Table 2 (cont.)

IV. Cell structure

(surface structures and polysaccharides, flagella)

\begin{tabular}{|c|c|c|}
\hline Gene name & Similarities & Reference \\
\hline$i p a-5 r$ & Alanine activating enzyme & \\
\hline$i p a-12 d$ & LPS 1,3-galactosyltransferase & \\
\hline$i p a-36 d$ & Galactose-1-P uridyltransferase & \\
\hline$i p a-62 r$ & Glutenin & Glaser et al. (1993) \\
\hline ipa-71d & Sugar-nucleotidylation enzyme & \\
\hline ipa-72d & UDP-N-acetylglucosamine epimerase & \\
\hline$i p a-73 d$ & Glucose-1-P thymidylyltransferase & \\
\hline$p b p B$ & Penicillin binding protein & Yanouri et al. (1993) \\
\hline $\operatorname{orf} X 10(\operatorname{dacB})$ & Penicillin binding protein & Sorokin et al. (1993) \\
\hline $\operatorname{orf} \times 16$ & Chloroplast protein & Sorokin et al. (1993) \\
\hline murE, mra $Y$, murD & $N$-Acetylmuramic acid-peptide synthesis & Daniel \& Errington (1993) \\
\hline$f i F, G, H, I$ & Flagellar biosynthesis & Albertini et al. (1991) \\
\hline$f i J, K, L, f g G$ & Flagellar biosynthesis & \\
\hline
\end{tabular}

V. Cellular processes

(transport/binding proteins, cell division, chemotaxis, protein secretion)

\begin{tabular}{|c|c|c|}
\hline Gene name & Similarities & Reference \\
\hline$i p a-16 d$ & PTS Enzyme II $\beta$-glucoside & \\
\hline $\operatorname{roc} C$ & Amino acid permease & Glaser et al. (1993) \\
\hline$i p a-42 d$ & FtsW, SpoVE & \\
\hline $\operatorname{sipS}$ & Signal peptidase & $\begin{array}{l}\text { Sorokin et al. (1993) and } \\
\text { van Dijl et al. (1992) }\end{array}$ \\
\hline $\operatorname{orf} X 20$ & Iron transport, FecI regulatory protein & Sorokin et al. (1993) \\
\hline $\operatorname{orf} X 21$ & Iron transport, FecR regulatory protein & Sorokin et al. (1993) \\
\hline orf6 & Methyl-accepting chemotaxis receptor protein & Albertini et al. (1991) \\
\hline
\end{tabular}

VI. Sporulation

\begin{tabular}{|c|c|c|}
\hline Gene name & Similarities & Reference \\
\hline spoVAF & Spore germination protein I & Sorokin et al. (1993) \\
\hline $\operatorname{spoIVA}$ & & Stevens et al. (1992) \\
\hline spoVD & & Daniel et al. (1994) \\
\hline
\end{tabular}

rescue. In the first method, an E. coli plasmid, a pDIA5304 derivative containing a $B$. subtilis DNA fragment, is integrated through homologous recombination in the $B$. subtilis chromosome, thus conferring chloramphenicol resistance to the host. This recombinant plasmid DNA, as well as adjacent $B$. subtilis DNA sequences, is then excised from the chromosome using a restriction enzyme with a single site within the polylinker of the plasmid and infrequent sites in $B$. subtilis chromosomal DNA. After circularization with T4 DNA ligase, the recombinant plasmid containing adjacent DNA sequences is cloned in E. coli strain TP611 (Glaser et al., 1993). In this strain ColE1 plasmids are maintained at a low copy number, thus avoiding high levels of expression of $B$. subtilis genes. However, cloning of some B. subtilis DNA fragments in this host proved unsuccessful. In these cases, a marker rescue method is applied which consists of integrating a selective marker into the $B$. subtilis chromosome via a double cross-over event. This marker, as well as adjacent DNA sequences, is then excised from the chromosome and directly cloned in $B$. subtilis using a replicative plasmid. Finally, in a limited number of cases $B$. subtilis genes were cloned by direct complementation of genetic markers.

The YAC library constructed by S. D. Ehrlich and coworkers covered more than $98 \%$ of the $B$. subtilis chromosome (Azevedo et al., 1993a), indicating that the YAC recombinant library covers a larger part of the $B$. subtilis chromosome. The drawback of this method, however, is that the yield of YAC recombinant DNA after purification is usually low.

The European laboratories, numbered from 1 to 10 , are each sequencing at least $20 \mathrm{~kb}$ of $B$. subtilis genomic DNA every year. The other European groups, numbered from 11 to 18 , which have recently joined the consortium, are 
also going to contribute at the same level. At this stage of the European project several fragments of more than $20 \mathrm{~kb}$ have already been sequenced, including contigs of $127 \mathrm{~kb}, 105 \mathrm{~kb}, 60 \mathrm{~kb}, 50 \mathrm{~kb}$ and $42 \mathrm{~kb}$. The average error rate is presently estimated to be lower than 1 per 2000 nucleotides. Appropriate quality controls are implemented to further improve this score. The estimated amounts of $B$. subtilis genomic DNA sequenced by the piecemeal approach or by the systematic approach in the framework of the European project are at present 600 and $500 \mathrm{~kb}$, respectively. By the end of 1996 the European consortium is expected to have contributed $1.5 \mathrm{Mb}$.

\section{Identified genes}

A list of putative genes, which were identified during this initial phase of the European project and which encode putative proteins showing similarities with proteins present in data banks, is presented in Table 2 . Additional genes which have recently been identified are also presented in several publications in this issue.

\section{Data handling}

A depository representing a collection of verified DNA sequences by the laboratories of the European consortium has been established at the Institut Pasteur. In addition, a specialized database is presently being built (Moszer $e t$ al., 1995). This database contains sequences in the depository as well as non-duplicate data concerning $B$. subtilis 168 which are already present in available libraries. Concomitantly, a task-driven, object-oriented database is being constructed allowing fast analysis of unknown sequences (Médigue et al., 1993).

\section{Release of the sequences}

Sequences in the depository at the Institut Pasteur are kept confidential for a period of 9 months following submission until verification has been completed satisfactorily. This process includes verification, under the responsibility of two of us (A.D. and F.K.), and resequencing up to $15 \%$ of the submitted sequence by a second laboratory of the network to minimize errors.

An agreement has been reached among the members of the network allowing them to forward, immediately after submission to the depository, the determined DNA sequences to other members of the European-Japanese consortium.

Finally, one of us (A.V.) will transmit a document containing similarities of putative $B$. subtilis proteins with proteins present in international data banks to European industries every 3 months to facilitate contacts and to establish possible bilateral interactions.

\section{Acknowledgements}

This work was supported by the European Commission under the Biotechnology programme (contract numbers BIO2-CT930272 and BIO2-CT94-2011). The work from our laboratories was supported by funds from Institut Pasteur and Centre
National de la Recherche Scientifique (URA 1300 and GDR 1029). We wish to thank G. Rapoport and P. Glaser for helpful discussions and C. Dugast for expert secretarial assistance.

\section{References}

Albertini, A. M., Caramori, T., Crabb, W. D., Scoffone, F. \& Galizzi, A. (1991). The fla $A$ locus of Bacillus subtilis is part of a large operon coding for flagellar structures, motility functions, and an ATPaselike polypeptide. J Bacteriol 173, 3573-3579.

Amjad, M., Castro, J. M., Sandoval, H., Wu, J. J., Yang, M., Henner, D. K. \& Piggot, P. J. (1990). An SfiI restriction map of the Bacillus subtilis 168 genome. Gene 101, 15-21.

Anagnostopoulos, C., Piggot, P. J. \& Hoch, J. A. (1993). The genetic map of Bacillus subtilis. In Bacillus and other Gram-Positive Bacteria: Biochemistry, Physiology and Molecular Genetics, pp. 425-461. Edited by A. L. Sonenshein, J. A. Hoch \& R. Losick. Washington, DC: American Society for Microbiology.

Azevedo, V., Alvares, E., Zumstein, E., Damiani, G., Sgaramella, V., Ehrlich, S. D. \& Seror, P. (1993a). An ordered collection of Bacillus subtilis DNA segments cloned in yeast artificial chromosomes. Proc Natl Acad Sci US A 90, 6047-6051.

Azevedo, V., Sorokin, A., Ehrlich, S. D. \& Seror, P. (1993b). The transcriptional organization of the Bacillus subtilis 168 chromosome region between spoV $A F$ and $\operatorname{ser} A$ genetic loci. Mol Microbiol 10, 397-405.

Bergh, S. \& Cole, S. T. (1994). MycDB: an integrated mycobacterial database. Mol Microbiol 12, 517-534.

Daniel, R. A. \& Errington, J. (1993). DNA sequence of the murE-murD region of Bacillus subtilis 168. J Gen Microbiol 139, 361-370.

Daniel, R. A., Drake, S., Buchanan, C. E., Scholle, R. \& Errington, J. (1994). The Bacillus subtilis spoVD gene encodes a mother-cellspecific penicillin-binding protein required for spore morphogenesis. J Mol Biol 235, 209-220.

van Dijl, J. M., de Jong, A., Vehmaanpera, J., Venema, G. \& Bron, S. (1992). Signal peptidase I of Bacillus subtilis: patterns of conserved amino acid in prokaryotic and eukaryotic type I signal peptidases. EMBO J 11, 2819-2828.

Dujon, B. and others (1994). Complete DNA sequence of yeast chromosome XI. Nature 369, 371-378.

Glaser, P., Kunst, F., Arnaud, M., Coudart, M.-P., Gonzales, W., Hullo, M.-F., lonescu, M., Lubochinsky, B., Marcelino, L., Moszer, I., Presecan, E., Santana, M., Schneider, E., Schweizer, J., Vertès, A., Rapoport, G. \& Danchin, A. (1993). Bacillus subtilis genome project : cloning and sequencing of the $97 \mathrm{~kb}$ region from $325^{\circ}$ to $333^{\circ}$. Mol Microbiol 10, 371-384.

Itaya, M. \& Tanaka, T. (1991). Complete physical map of the Bacillus subtilis 168 chromosome constructed by a gene-directed mutagenesis method. J Mol Biol 220, 631-648.

Kunst, F. \& Devine, K. (1991). The project of sequencing the entire Bacillus subtilis genome. Res Microbiol 142, 905-912.

Magnien, E., Bevan, M. \& Planqué, K. (1992). A European 'BRIDGE' project to tackle a model plant genome. Trends Biotechnol 10, 12-15.

Médigue, C., Willamowski, J., Schmeltzer, O., Uvietta, P., Rechenmann, F., Chevenet, F., Perrière, G. \& Gautier, C. (1993). Modeling tasks for problem solving in molecular biology. In Abstracts of the International Joint Conference on Artificial Intelligence, pp. 67-76. Chambéry, France.

Moszer, I., Glaser, P. \& Danchin, A. (1995). SubtiList: a relational database for the Bacillus subtilis genome. Microbiology 141, 261-268. 
Ogasawara, N., Fujita, Y., Kobayashi, Y., Sadaie, Y., Tanaka, T., Takahashi, H., Yamane, K. \& Yoshikawa, H. (1995). Systematic sequencing of the Bacillus subtilis genome: progress report of the Japanese group. Microbiology 141, 257-259.

Oliver, S. G. and others (1992). The complete DNA sequence of yeast chromosome III. Nature 357, 38-46.

O'Reilly, M. \& Devine, K. M. (1994). Sequence and analysis of the citrulline biosynthetic operon $\arg C-F$ from Bacillus subtilis. Microbiology 140, 1023-1025.

Peterson, S. N., Hu, P. C., Bott, K. F. \& Hutchison, C. A., III (1993). A survey of the Mycoplasma genitalium genome by using random sequencing. J Bacteriol 175, 7918-7930.

Riley, M. (1993). Functions of the gene products of Eschericbia coli. Microbiol Rev 57, 862-952.

Santana, M., lonescu, M. S., Vertès, A., Longin, R., Kunst, F., Danchin, A. \& Glaser, P. (1994). Bacillus subtilis $\mathrm{F}_{0} \mathrm{~F}_{1}$ A TPase: DNA sequence of the ATP operon and characterization of atp mutants. $J$ Bacteriol 176, 6802-6811.

Scotti, C., Piatti, M., Cuzzoni, A., Perami, P., Tognoni, A., Grandi, G., Galizzi, A. \& Albertini, A. M. (1993). A Bacillus subtilis large ORF coding for a polypeptide highly similar to polyketide synthases. Gene 130, 65-71.

Sofia, H. J., Burland, V., Daniels, D. L., Plunkett, G., III \& Blattner,
F. R. (1994). Analysis of the Eschericbia coli genome. V. DNA sequence of the region from 76 to 81.5 minutes. Nucleic Acids Res 22, 2576-2586.

Sorokin, A., Zumstein, E., Azevedo, V. A., Ehrlich, S. D. \& Seror, P. (1993). The organization of the Bacillus subtilis 168 chromosome region between spoV $A$ and ser $A$ genetic loci, based on sequencing data. Mol Microbiol 10, 385-395.

Stevens, C. M., Daniel, R., Illing, N. \& Errington, J. (1992). Characterization of a sporulation gene, spoIV $A$, involved in spore coat morphogenesis in Bacillus subtilis. $J$ Bacteriol 174, 586-594.

Vassarotti, A. \& Goffeau, A. (1992). Sequencing the yeast genome: the European effort. Trends Biotechnol 10, 15-18.

Wilson, R. and others (1994). $2.2 \mathrm{Mb}$ of contiguous nucleotide sequence from chromosome III of C. elegans. Nature 368, 32-38.

Woese, C. R. (1987). Bacterial evolution. Microbiol Rev 51, 221-271. Yanouri, A., Daniel, R. A., Errington, J. \& Buchanan, C. E. (1993). Cloning and sequencing of the cell division gene $p b p B$, which encodes penicillin-binding protein 2B in Bacillus subtilis. $J$ Bacteriol $175,7604-7616$.

Received 13 July 1994; revised 15 September 1994; accepted 3 October 1994. 